\title{
Validation of impregnation process for homeopathic globules by spectrophotometric-UV method
}

\author{
Mariana Santos Pinheiro","*, Paula Fernandes de Aguiar $^{2}$, Carla Holandino Quaresma ${ }^{3}$, Sheila \\ Garcia $^{3}$
}

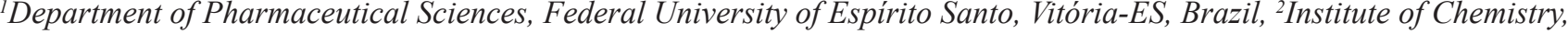
Federal University of Rio de Janeiro, UFRJ, Rio de Janeiro, Brazil, ${ }^{3}$ Department os Medicamentes, Faculty of Pharmacy, Federal University of Rio de Janeiro, Rio de Janeiro, Brazil
\end{abstract}

\begin{abstract}
We compared the impregnation techniques for globules according to the Manual of Technical Norms for Homeopathic Pharmacies (MNTFH) of the Association of Homeopathic Pharmacists (ABFH), Brazilian Homeopathic Pharmacopoeia (FHB) and variations of these techniques. The variables were evaluated in this procedure, three different sizes of globules ( $\mathrm{N}^{\circ}$. 3, 5 and 7), the hydroalcoholic solution of $70 \%$ $(\mathrm{v} / \mathrm{v})$ Minoxidil 2\% (w/v) was used to impregnate the globules in concentrations of 2, 3, 4, 5\% (v/w) and the impregnation at $10 \%(\mathrm{v} / \mathrm{w})$ was used hydroalcoholic solutions at 70, 80 and $90 \%(\mathrm{v} / \mathrm{v})$, and four impregnation techniques various (A-glass, B-paper, C-cup and D-FHB). As the results of content uniformity did not demonstrate a normal distribution, the one way ANOVA and a nonparametric statistical model were used for evaluation. Considering the average, the standard deviation (SD), the individual variance of each group and the principal components analysis graphs (PCA), it was observed that the "A" impregnation of globules technique, with $5 \%(\mathrm{v} / \mathrm{w})$ of the impregnation concentrations and the No.5 globule presented the best uniformity of dose. As to the drying, there was a need to use a heat source.
\end{abstract}

Uniterms: Homeopathic globules/impregnation process. Homeopathic compounding/evaluation. Homeopathic dose/uniformity of content.

\begin{abstract}
Compararam-se as técnicas de impregnação para glóbulos segundo o Manual de Normas Técnicas para Farmácias Homeopáticas (MNTFH) da Associação Brasileira de Farmacêuticos Homeopatas (ABFH), Farmacopeia Homeopática Brasileira (FHB) e variações destas técnicas. As variáveis avaliadas neste processo foram: três tamanhos diferentes de glóbulos (n. ${ }^{\circ} 3,5$ e 7); a solução hidroalcóolica a 70\% (v/v) de minoxidil a $2 \%(\mathrm{p} / \mathrm{v})$ foi utilizada para impregnar os glóbulos nas concentrações de 2, 3, 4, 5\% (v/p) e na impregnação a 10\% (v/p) utilizaram-se as soluções hidroalcóolicas a 70, 80 e $90 \%$ (v/v); e quatro técnicas de impregnação diferentes (A-vidro, B-papel, C-copo e D-FHB). A impregnação foi validada através da uniformidade de dose por conteúdo, sendo o minoxidil a substância quantificada. Como os resultados da uniformidade de dose por conteúdo não demonstraram distribuição normal, utilizaram-se o One way ANOVA e um modelo estatístico não paramétrico para sua avaliação. Considerando-se a média, o desvio padrão (DP), a variância individual de cada grupo e os gráficos de análise de componentes principais (ACP), observou-se que a impregnação que utilizou o glóbulo $\mathrm{n}^{\circ} 5$, a concentração para impregnação de 5\% (v/p), graduação alcoólica de 70\% (v/v) e técnica "A" apresentou a melhor uniformidade de dose. Quanto à secagem, verificou-se a necessidade do uso de uma fonte de calor.
\end{abstract}

Unitermos: Glóbulos homeopáticos/processo de impregnação. Composição homeopática/avaliação. Dose homeopática/uniformidade de conteúdo.

\footnotetext{
*Correspondence: M. S. Pinheiro. Departamento de Ciências Farmacêuticas, Universidade Federal do Espírito Santo. Av. Marechal Campos, 1468 - Maruípe, 29040090 - Vitória - ES, Brasil. E-mail: pinheiroms@terra.com.br; mariana.pinheiro@ufes.br
} 


\section{INTRODUCTION}

The globule, a pharmaceutical form of solid internal use, was evaluated in this study, as for uniformity of impregnation. There are differences in the available texts for consultation on how the impregnation happens (Farmacopeia Homeopática Brasileira., 1997; ABFH, 2007; Fontes, 2005; Gutierrez, Maciel, 2001). There are also disagreements over this issue in the homeopathy official compendia in several countries. This difficulty regarding standardization in the form of impregnation begins in the work left by Hahnemann--the Organon, in which he does not describe the technique in detail.

Hahnemann describes in the paragraph 270 of the Organon $\left(6^{\text {th }}\right.$ edition $)$ the technique of impregnation of the microglobules used in the preparation of Fifty Milesimal (LM) (Tétau, 2001). These are much smaller and they are used in the process of the drop division (the last step of LM) and not to the final impregnation of the globules for dispatching.

Many pharmacopoeias report on the different types of globules impregnation, for instance: the German (German, 1991), the American (The Homeopathic, 1999), the Mexican (Farmacopoea, 1998), from the United States of Mexico (Sandoval, 1961), from India (Homeopathic, 1984), the French (Syndicat, 1979) and from Scotland (Kayne, 1997). In these references the techniques differ in the size of the globules, the concentration of the solution and the alcoholic content of the impregnating solution, and in the globule impregnation technique used in homeopathy.

The validation process is defined as "the establishing of documented evidences that prove that a specific process will consistently produce a product with high level of safety and that keeps its predetermined specifications and the characteristics of quality" (FDA, 2005). The validation process is intended to ensure the safety of the manufacturing process, following the proposed objective and making the process reproducible. For considering a process validated it is indispensable that the methods of analysis are also validated.

In this work, it was developed a not tendentious method to validate the globule impregnation technique, focusing on the different existing variables and making that the impregnations were resembled to the daily reality of homeopathic pharmacies. The use of minoxidil solution, which is colorless, instead of a dye allowed an impregnation closer to the reality of homeopathic pharmacies (Araújo et al., 2004; Gutierrez, 2001; Pozetti, Silva, Pizzolitto, 2002; Rocha et al., 2000; Diehl et al., 2008).

\section{MATERIAL AND METHODS}

\section{Material}

\section{Inputs}

Distilled water; monobasic potassium phosphate $\left(\mathrm{KH}_{2} \mathrm{PO}_{4}\right)$ - phosphate buffer ( $\left.\mathrm{pH} 7.2\right)$; ethyl alcohol; minoxidil base (Spectrum Química; batch No. 20040207), sucrose inert globule No.3 (average weight of $30 \mathrm{mg}$; batch $\mathrm{N}^{\circ} .62 / \mathrm{C}$ ); sucrose inert globule No.5 (average weight of $50 \mathrm{mg}$, lot No.G5210704) and sucrose inert globule No.7 (average weight of $70 \mathrm{mg}$, lot No. G7270704). All of them were donated by Laboratório Schraibmann Ltda..

\section{Equipments}

Volumetric flask; Glassini paper; stainless steel spatula; disposable cup $(50 \mathrm{~mL})$; graduated glass cylinder; amber glass bottle with lid $(30 \mathrm{~mL})$; automatic pipettes 200 and $1000 \mu \mathrm{L}$ (Eppendorf Research ${ }^{\circledR}$ ); quartz cuvette; alcoholmeter of Gay Lussac; maximum/minimum Thermohygrometer; stove; ultrasound (Thornton T4); Stopwatch (SW2018 Cronobio); spectrophotometer (UV2401 PC Shimadzu); magnetic board (Corning Stirrer) and analytical balance (Mettler Toledo AG204).

\section{Computer resources}

Microsoft Excel ${ }^{\circledR}$ program (Windows) and a statistical program for PCA graphics (The Unscrambler ${ }^{\circledR}$ ).

\section{Methods}

The variables studied in this work are: three sizes of globules ( $\mathrm{N}^{\circ} 3,5$ and 7); five different concentrations of impregnation: $2,3,4,5$ and $10 \%(\mathrm{v} / \mathrm{w})$; four different impregnation techniques: A-glass, B-paper, C-cup and D-BHP; three different alcoholic content for the impregnating solution $(70,80$ and $90 \%(\mathrm{v} / \mathrm{v}))$, which were only tested for the technique of Brazilian Homeopathic Pharmacopeia (BHP) 2nd edition, this procedure was conducted because the intention was to verify if there was a significant difference in the alcoholic graduation in the globule impregnation.

Minoxidil was the marker chosen due to the fact that it is soluble in hydroalcoholic solution and is a colorless solution for globule impregnation (The Merck, 2006). The impregnation solutions were done with minoxidil at $2 \%(\mathrm{w} / \mathrm{v})$ in hydroalcoholic solutions at 70,80 e $90 \%$ $(\mathrm{v} / \mathrm{v})$. Minoxidil hydroalcoholic solution at $70 \%(\mathrm{v} / \mathrm{v})$ was used to impregnate the globules at concentrations of 2, 3, 4, 5\% (v/w) as MTNHP 4th edition (ABFH, 2007), and the three solutions 70,80 and $90 \%(\mathrm{v} / \mathrm{v})$ was used to 
impregnate at the concentration of $10 \%(\mathrm{v} / \mathrm{w})$ according to BHP (Farmacopeia, 1997). All the impregnations were performed in triplicate.

Considering the research done between Rio de Janeiro and Espírito Santo Homeopathic Pharmacies the techniques chosen were (Pinheiro, Garcia, 2006):

- $\quad$ Technique A (A-glass): amber glass with simple impregnation was used to reproduce the technique described by homeopathic compounding pharmacies.

- Technique B (B-paper): glassine paper, triple impregnation.

- $\quad$ Technique C (C-cup): plastic cup (polyethylene), triple impregnation

- $\quad$ Technique D (D-FHB): related by BHP 2nd edition the technique consists of triple impregnation at $10 \%$ $(\mathrm{v} / \mathrm{w})$. The amber glass has also been chosen to perform the impregnations, since in BHP there is no mention where the globules should be impregnated.

The drying time was evaluated for the techniques $\mathrm{A}, \mathrm{B}$ and $\mathrm{C}$ under ambient conditions for impregnation concentrations from 2 to $5 \%(\mathrm{v} / \mathrm{w})$ of the minoxidil at $2 \%$ $(\mathrm{w} / \mathrm{v})$ in hydroalcoholic solutions at $70 \%(\mathrm{v} / \mathrm{v})$. The drying was performed with a stove at $45 \pm 3^{\circ} \mathrm{C}$ for the technique $\mathrm{D}$ at the impregnation concentration of $10 \%(\mathrm{v} / \mathrm{w})$ of the minoxidil at $2 \%(\mathrm{w} / \mathrm{v})$ in hydroalcoholic solutions at 70,80 and $90 \%(\mathrm{v} / \mathrm{v})$. Both of them were weighed on an analytical balance and dry to constant mass. Analyzes were done in triplicate, determining the average $(\mathrm{X})$, the standard deviation (SD) and the coefficient of variance (CV). Statistical analysis was performed from all obtained results.

Subsequently, the globules were analyzed according to content uniformity, as described in the Brazilian Pharmacopeia (2010), for tablets and capsules.

The analytical methodology described by USP 27 (2004) is the ultraviolet radiation, using phosphate buffer solution $\mathrm{pH} 7.2$ at $285 \mathrm{~nm}$. The analytical standard curve was done with five concentrations of minoxidil secondary standard at 1.0, 5.0, 10.0, 30.0 and $50.0 \mu \mathrm{g} / \mathrm{mL}$ (Table I)

The calculation performed to obtain the results of the

TABLE I - Items of spectrophotometric standard curve

\begin{tabular}{lc}
\hline $\begin{array}{l}\text { Linear regression equation } \\
\text { of zero order }\end{array}$ & $\mathrm{y}=-0.007+0.058 \mathrm{x}$ \\
Correlation coefficient $(\mathbf{r})$ & 0.9999 \\
Coefficient of determination $\left(\mathbf{R}^{2}\right)$ & 0.9999 \\
Range of linearity & $1-50$ \\
\hline
\end{tabular}

content uniformity was done as described in the Equation A. The mass of minoxidil was determined for the two globules diluted in phosphate buffer $\mathrm{pH} 7.2$ in a $25.0 \mathrm{~mL}$ volumetric flask.

\section{Equation A:}

$\%$ for each dose determination $=\frac{\mathrm{Ca} \times \mathrm{Vd} \times \mathrm{PTG} \times 100}{(\mathrm{nMx}-\mathrm{R}) \times \mathrm{PTG}}$

$\mathrm{Ca}=$ concentration of minoxidil determined by the standard curve; $\mathrm{Vd}=$ volume of dilution; $\mathrm{PTG}=$ total weight of two globules; $\mathrm{R}=$ residue; $\mathrm{mM} x=$ mass of minoxidil corrected.

Grubbs test was applied with 95\% level of confidence for the elimination of the outliers. According to Leite (2008), "eliminating values visually is something simple however it is more difficult to justify the rejection. The rejection systems are used to center the values on the average".

Other statistical tools were used with the results of the content uniformity: individual variance, one-way ANOVA and Principal Component Analysis (PCA) (Massart et al., 1998). These statistical tools used computer programs such as Windows Excel ${ }^{\circledR}$ and The Unscrambler ${ }^{\circledR}$.

\section{RESULTS AND DISCUSSION}

The choice of the globule size, the concentration and the technique of impregnation were essential for the preparation of the pharmaceutical dosage form "globule" as a homeopathic medicine. This study aimed to demonstrate through a scientific methodology, using statistical tools, official compendia, calibrated materials and equipment, the existence or not of differences among the four study variables.

The assessment for homogeneity impregnation of the globules with a hydroalcoholic solution of minoxidil at $2 \%(\mathrm{w} / \mathrm{v})$ was performed using the content uniformity. The results were demonstrated on the Table II.

\section{Concerning the size of the globule}

Usually, as the larger the globule, the greater is the variation of impregnation (Table II).

\section{Concerning the concentration of impregnation}

The lowest values of $\mathrm{CV}$ were determined to concentration of impregnation at $10 \%(\mathrm{v} / \mathrm{w})$ followed by the concentration of impregnation at $5 \%(\mathrm{v} / \mathrm{w})$ for all 
three sizes of globules and the three techniques evaluated (Table II).

\section{Concerning the impregnation technique}

For all three sizes of globules it was observed that the technique A has smaller CV, except for the globule $\mathrm{N}^{\circ} .7$ at a concentration of impregnation at $3 \%(\mathrm{v} / \mathrm{w})$. The technique $\mathrm{B}$ had the largest differences in impregnation of globules (Table II).

\section{Concerning the hydroalcoholic solution concentration of impregnating}

The concentration of $70 \%(\mathrm{v} / \mathrm{v})$ had lower CV levels for globules $\mathrm{N}^{\circ} .3$ and 7 and for the globule No.5 the lowest CV was observed for the alcohol graduation of $90 \%(\mathrm{v} / \mathrm{v})$ (Table III).

The variance for each studied group was demonstrated on the Table IV.

The results for the variance of each group indicate that for the concentrations of impregnation from 2 to 5 and $10 \%(\mathrm{v} / \mathrm{w})$, the technique A-glass is highlighted with the lowest results, occurring only one exception to the globule no. 3 which for this concentration technique C-cup got smaller variance. The D-BHP the lowest results were to the hydroalcoholic solution at $70 \%(\mathrm{v} / \mathrm{v})$ to the globule no. 3 and 7.

Another statistical tool that was used was ANOVA. This test compares data groups and aims to identify the

TABLE II - Results of the content uniformity of the globules No.3, 5 and 7 for the techniques A-glass, B-paper and C-cup in concentrations of impregnation at 2, 3, 4, 5 and $10 \%(\mathrm{v} / \mathrm{w})$ using hydroalcoholic solution of $70 \%(\mathrm{v} / \mathrm{v})$. The number of samples used in the content uniformity was 30 (for each variable), and after outliers removal, was calculate the average (X), the standard deviation (SD) and coefficient of variance $(\mathrm{CV})$

\begin{tabular}{|c|c|c|c|c|c|c|c|c|c|c|c|c|c|c|c|c|}
\hline \multirow{3}{*}{ 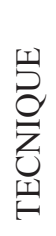 } & \multirow{3}{*}{ 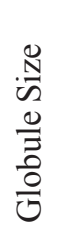 } & \multicolumn{15}{|c|}{ Concentration of Impregnation } \\
\hline & & \multicolumn{3}{|c|}{$2 \%(\mathrm{v} / \mathrm{w})$} & \multicolumn{3}{|c|}{$3 \%(\mathrm{v} / \mathrm{w})$} & \multicolumn{3}{|c|}{$4 \%(\mathrm{v} / \mathrm{w})$} & \multicolumn{3}{|c|}{$5 \%(\mathrm{v} / \mathrm{w})$} & \multicolumn{3}{|c|}{$10 \%(v / w)$} \\
\hline & & $\mathrm{X}$ & $\mathrm{SD}$ & $\mathrm{CV}$ & $\mathrm{X}$ & $\mathrm{SD}$ & $\mathrm{CV}$ & $\mathrm{X}$ & $\mathrm{SD}$ & $\mathrm{CV}$ & $\mathrm{X}$ & SD & $\mathrm{CV}$ & $\mathrm{X}$ & $\mathrm{SD}$ & $\mathrm{CV}$ \\
\hline $\mathbf{A}$ & & 112.0 & 62.0 & $55 \%$ & 127.6 & 49.7 & $39 \%$ & 97.5 & 29.8 & $31 \%$ & 114.5 & 32.9 & $29 \%$ & 118.7 & 19.2 & $16 \%$ \\
\hline $\mathbf{B}$ & 3 & 48.1 & 73.6 & $153 \%$ & 82.0 & 67.0 & $82 \%$ & 100.4 & 76.7 & $76 \%$ & 105.1 & 70.4 & $67 \%$ & 108.3 & 39.7 & $37 \%$ \\
\hline $\mathbf{C}$ & & 140.9 & 113.7 & $81 \%$ & 140.6 & 86.8 & $62 \%$ & 92.5 & 45.1 & $49 \%$ & 111.4 & 45.0 & $40 \%$ & 113.0 & 19.0 & $17 \%$ \\
\hline $\mathbf{A}$ & & 105.1 & 56.9 & $54 \%$ & 131.6 & 79.2 & $60 \%$ & 112.7 & 41.0 & $36 \%$ & 106.4 & 26.6 & $25 \%$ & 109.6 & 16.5 & $15 \%$ \\
\hline B & 5 & 71.9 & 106.5 & $148 \%$ & 103.3 & 104.3 & $101 \%$ & 108.4 & 96.7 & $89 \%$ & 87.2 & 79.8 & $92 \%$ & 106.9 & 33.6 & $31 \%$ \\
\hline C & & 146.7 & 120.1 & $82 \%$ & 117.8 & 86.9 & $74 \%$ & 123.6 & 72.0 & $58 \%$ & 133.7 & 70.8 & $53 \%$ & 108.6 & 20.9 & $19 \%$ \\
\hline $\mathbf{A}$ & & 96.9 & 59.0 & $61 \%$ & 114.6 & 76.4 & $67 \%$ & 94.2 & 44.3 & $47 \%$ & 120.9 & 50.1 & $41 \%$ & 104.6 & 19.2 & $18 \%$ \\
\hline B & 7 & 103.0 & 113.7 & $110 \%$ & 93.4 & 88.0 & $94 \%$ & 107.2 & 61.1 & $57 \%$ & 119.2 & 64.5 & $54 \%$ & 103.7 & 29.9 & $29 \%$ \\
\hline $\mathrm{C}$ & & 91.4 & 75.3 & $82 \%$ & 139.0 & 81.1 & $58 \%$ & 98.4 & 71.6 & $73 \%$ & 113.0 & 62.0 & $55 \%$ & 107.1 & 29.6 & $28 \%$ \\
\hline
\end{tabular}

$\mathrm{SD}=$ standard deviation; $\mathrm{X}=$ average; $\mathrm{CV}=$ coefficient of variance; $\mathrm{CV}=\mathrm{SD} / \mathrm{X}$

TABLE III - Results of the content uniformity of the globules $\mathrm{N}^{\circ} .3,5$ and 7 for the D-BHP in the concentration of impregnation at $10 \%(\mathrm{v} / \mathrm{w})$ using hydroalcoholic solutions at concentrations 70,80 and $90 \%(\mathrm{v} / \mathrm{v})$

\begin{tabular}{|c|c|c|c|c|c|c|c|c|c|}
\hline \multicolumn{10}{|c|}{ Technique D-BHP $10 \%(\mathrm{v} / \mathrm{w})$} \\
\hline & \multicolumn{3}{|c|}{$70 \%(v / v)$} & \multicolumn{3}{|c|}{$80 \%(v / v)$} & \multicolumn{3}{|c|}{$90 \%(v / v)$} \\
\hline & $X$ & SD & $\mathrm{CV}$ & $\mathbf{X}$ & SD & $\mathrm{CV}$ & $\mathbf{X}$ & SD & $\mathrm{CV}$ \\
\hline Globule No. 3 & 110.0 & 22.3 & $20 \%$ & 110.7 & 31.0 & $28 \%$ & 108.9 & 29.6 & $27 \%$ \\
\hline Globule No. 5 & 113.6 & 34.4 & $30 \%$ & 103.6 & 35.1 & $34 \%$ & 114.1 & 28.6 & $25 \%$ \\
\hline Globule No.7 & 97.8 & 30.8 & $31 \%$ & 103.2 & 41.5 & $40 \%$ & 107.5 & 49.3 & $46 \%$ \\
\hline
\end{tabular}

$\mathrm{SD}=$ Standard deviation $; \mathrm{X}=$ average $\mathrm{CV}=$ coefficient of variance $\mathrm{CV}=\mathrm{SD} / \mathrm{X}$ 
TABLE IV - Variance results obtained by the content uniformity for all studied groups

\begin{tabular}{|c|c|c|c|c|c|c|c|}
\hline \multirow{2}{*}{$\begin{array}{l}\text { Globule } \\
\text { Size }\end{array}$} & \multirow{2}{*}{$\begin{array}{l}\text { Concentration of the } \\
\text { impregnation }\end{array}$} & \multicolumn{6}{|c|}{ Impregnation Techniques } \\
\hline & & A-glass & B-paper & C-cup & $\begin{array}{c}\text { D- BPH } \\
70 \%(\mathrm{v} / \mathrm{v}) \\
\end{array}$ & $\begin{array}{c}\text { D- BPH } \\
80 \%(\mathrm{v} / \mathrm{v}) \\
\end{array}$ & $\begin{array}{c}\text { D- BPH } \\
90 \%(\mathrm{v} / \mathrm{v}) \\
\end{array}$ \\
\hline \multirow{5}{*}{ 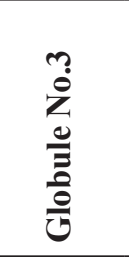 } & $2 \%(v / w)$ & $3,837.9$ & $5,411.4$ & $12,935.4$ & - & - & - \\
\hline & $3 \%(v / w)$ & $2,473.5$ & $4,495.4$ & $7,534.2$ & - & - & - \\
\hline & $4 \%(v / w)$ & 889.2 & $5,877.4$ & $2,036.3$ & - & - & - \\
\hline & $5 \%(v / w)$ & $1,082.7$ & $4,949.1$ & $2,025.2$ & - & - & - \\
\hline & $10 \%(v / w)$ & 366.9 & $1,572.8$ & 360.7 & 496.1 & 962.0 & 874.9 \\
\hline \multirow{5}{*}{$\begin{array}{l}n \\
0 \\
0 \\
0 \\
0 \\
0 \\
0 \\
0\end{array}$} & $2 \%(v / w)$ & $3,239.7$ & $11,334.7$ & $14,424.7$ & - & - & - \\
\hline & $3 \%(v / w)$ & $6,274.3$ & $10,868.7$ & $7,550.2$ & - & - & - \\
\hline & $4 \%(v / w)$ & $1,681.9$ & $9,357.7$ & $5,185.6$ & - & - & - \\
\hline & $5 \%(v / w)$ & 705.0 & $6,364.2$ & $5,017.6$ & - & - & - \\
\hline & $10 \%(v / w)$ & 271.6 & $1,131.1$ & 437.0 & $1,186.6$ & $1,233.0$ & 820.7 \\
\hline \multirow{5}{*}{$\begin{array}{l}\hat{0} \\
\dot{z} \\
0 \\
\overline{0} \\
\dot{0}\end{array}$} & $2 \%(v / w)$ & $3,477.4$ & $12,929.2$ & $5,663.5$ & - & - & - \\
\hline & $3 \%(v / w)$ & $5,837.3$ & $7,740.2$ & $6,580.1$ & - & - & - \\
\hline & $4 \%(v / w)$ & $1,963.9$ & $3,737.4$ & $5,127.1$ & - & - & - \\
\hline & $5 \%(v / w)$ & $2,505.5$ & $4,154.9$ & $3,849.2$ & - & - & - \\
\hline & $10 \%(v / w)$ & 369.8 & 895.5 & 874.7 & 950.8 & $1,720.6$ & $2,431.5$ \\
\hline
\end{tabular}

existence of at least one difference between groups. This difference is observed when $\mathrm{F}_{\text {calculated }}$ is superior to $\mathrm{F}_{\text {critical }}$ (fixed value).

The value of $\mathrm{F}_{\text {calculated }}$ less than 1 indicates that the variance within each group is greater than the variance among the groups, thus it is impossible to identify differences between groups (Callegari-Jacques, 2003).

The comparison of the values of a set of results with the real value or with the values of other sets of results allows verifying the equivalence or not of the different techniques and concentrations of impregnation (Mendham et al., 2002). In this way, the obtained results by the content uniformity test, from different impregnation techniques in analysis, were compared by the variance ratio test (test F- ANOVA), obtaining a statistical evaluation of the data obtained (Table V, VI and VII).

For the globule $\mathrm{N}^{\mathrm{o}} .3$ (Table V) the techniques A-glass, B-paper, C-cup and D-BHP at 10\% (v/w) do not have statistically significant difference. However the techniques A-glass and C-cup, in the concentrations of impregnation from 2 to $5 \%(\mathrm{v} / \mathrm{w})$ presented $\mathrm{F}_{\text {calculated }}$ value lower than $\mathrm{F}_{\text {critical }}$, i.e. the variance among the groups of concentrations is higher than the individual variance of each group, but nothing that leads to a statistically significant difference. The B-paper technique, in concentrations from 2 to $5 \%$ $(\mathrm{v} / \mathrm{w})$ presented a $\mathrm{F}_{\text {calculated }}$ greater than the $\mathrm{F}_{\text {critical }}$, concluding that there is a concentration among these measured ones that produces globules more evenly impregnated, i.e., the concentration of impregnation to this technique produces different results.

TABLE V - ANOVA test for the four techniques at concentrations of 2, 3, 4, 5 and 10\% (v/w) - globule $\mathrm{N}^{\circ} .3$

GLOBULE No. 3

\begin{tabular}{lcc}
\hline Technique/ concentration of impregnation & $\mathbf{F}_{\text {calculated }}$ & $\mathbf{F}_{\text {critical }}$ \\
\hline A-glass / 2, 3,4 e 5\%(v/w) & $\mathbf{2 . 0 8 8}$ & 2.686 \\
B-paper / 2, 3,4 e 5 \%(v/w) & 3.627 & 2.685 \\
C-cup / 2, 3,4 e 5 \%(v/w) & $\mathbf{2 . 6 2 4}$ & 2.684 \\
A-glass, B-paper, C-cup and D-BHP 10 \%(v/w) & 0.899 & 2.683 \\
D-BHP 10 \%(v/w) - 70, 80 and 90 \%(v/v) & 0.032 & 3.101 \\
\hline
\end{tabular}


TABLE VI - ANOVA test for the four techniques at concentrations of 2, 3, 4, 5 and $10 \%(\mathrm{v} / \mathrm{w})$ - globule No.5

\begin{tabular}{lcc}
\hline & GLOBULE No. 5 & \\
\hline Technique/ concentration of impregnation & $\mathbf{F}_{\text {calculated }}$ & $\mathbf{F}_{\text {critical }}$ \\
\hline A-glass / 2, 3,4 e 5 \%(v/w) & $\mathbf{1 . 5 0 8}$ & 2.683 \\
B-paper / 2, 3,4 e 5 \%(v/w) & 0.841 & 2.684 \\
C-cup / 2, 3,4 e 5 \%(v/w) & 0.598 & 2.683 \\
A-glass, B-paper, C-cup and D-BHP 10 \%(v/w) & 0.318 & 2.683 \\
D-BHP 10 \%(v/w) - 70, 80 and 90 \%(v/v) & 0.963 & 3.101 \\
\hline
\end{tabular}

TABLE VII - ANOVA test for the four techniques at concentrations of 2, 3, 4, 5 and $10 \%(\mathrm{v} / \mathrm{w})$ - globule №.7

\begin{tabular}{lcc}
\hline & GLOBULE No.7 & \\
\hline Technique/ concentration of impregnation & F $_{\text {calculated }}$ & F $_{\text {critical }}$ \\
\hline A-glass / 2, 3,4 e 5 \%(v/w) & $\mathbf{1 . 4 8 1}$ & 2.684 \\
B-paper / 2, 3,4 e 5 \%(v/w) & 0.479 & 2.683 \\
C-cup / 2, 3,4 e 5 \%(v/w) & $\mathbf{2 . 4 5 9}$ & 2.684 \\
A-glass, B-paper, C-cup and D-BHP 10 \%(v/w) & 0.606 & 2.684 \\
D-BHP 10 \%(v/w) - 70, 80 and 90 \%(v/v) & 0.417 & 3.101 \\
\hline
\end{tabular}

For the globule No.5 (Table VI), it is also observed that there is no statistically significant difference for the techniques used within concentrations of impregnating studied. This means that for this globule size and technique the impregnation concentrations in the range from 2 to $5 \%$ $(\mathrm{v} / \mathrm{w})$ produce globules with a smaller variance, which is impregnate more homogeneously.

However, when we performed the ANOVA, comparing the $\mathrm{F}_{\text {calculated }}$ with $\mathrm{F}_{\text {critical }}$, it was noted that for the globule No.7, the techniques are statistically equivalent and there is no difference between impregnation concentrations for each technique. For the techniques A-glass and C-cup it was obtained the $\mathrm{F}_{\text {calculated }}$ value greater than 1 but smaller than the $\mathrm{F}_{\text {critical }}$ (Table VII)

It was evaluated the best alcoholic content from the impregnation solutions to be used, technique D-BHP (Tables V, VI and VII). Impregnations were made with hydroalcoholic solutions of minoxidil at 70, 80 and $90 \%$ $(\mathrm{v} / \mathrm{v})$. According to the results of ANOVA, it is observed that when the hydroalcoholic solutions of the impregnation were changed to the globules no. 3, 5 and $7 \mathrm{~F}_{\text {calculated }}$ is less than 1 , i.e. the variance inside each group was so large that it was impossible to compare the results between the groups.

The need for a normal distribution is essential for some statistical tools (parametric tests) may be applicable. In the case of ANOVA, the lack of a normal distribution does not affect the reliability of the obtained results since this test is very strong and provides reliable results (Callegari-Jacques, 2003).

The Principal Components Analysis (PCA) is a multivariate statistical technique that consists of transforming a set of original variables into another set of variables of same dimension called principal components. The main components demonstrate important properties: each main component is a linear combination of all the original variables, they are independent of each other and they are expected to retain the maximum amount of information in terms of total variation contained in the data. The analysis of the principal components is associated with the idea of mass reduction data with the least possible loss of information (Varella, 2008).

The PCA corroborates with the results discussed so far, since it made possible to identify differences between the techniques, the concentrations of impregnation and the sizes of the globules. Despite the quantum of data available, the ability to obtain a clear picture of what going on helps to analyze a great number of dates. It is useful when involves more than a single variable.

In the PCA figure (Figures 1, 2 and 3), is possible to observe the comportment of four techniques and concentrations of impregnation $(2,3,4$ and $5 \%(\mathrm{v} / \mathrm{w}))$ for each globule size ( $\mathrm{N}^{\circ} .3,5$ and 7$)$.

It was possible to identify a globule size that produced results with smaller variances in the general analysis. Comparing the globule $\mathrm{N}^{0} .5$ (Figure 2) to the 


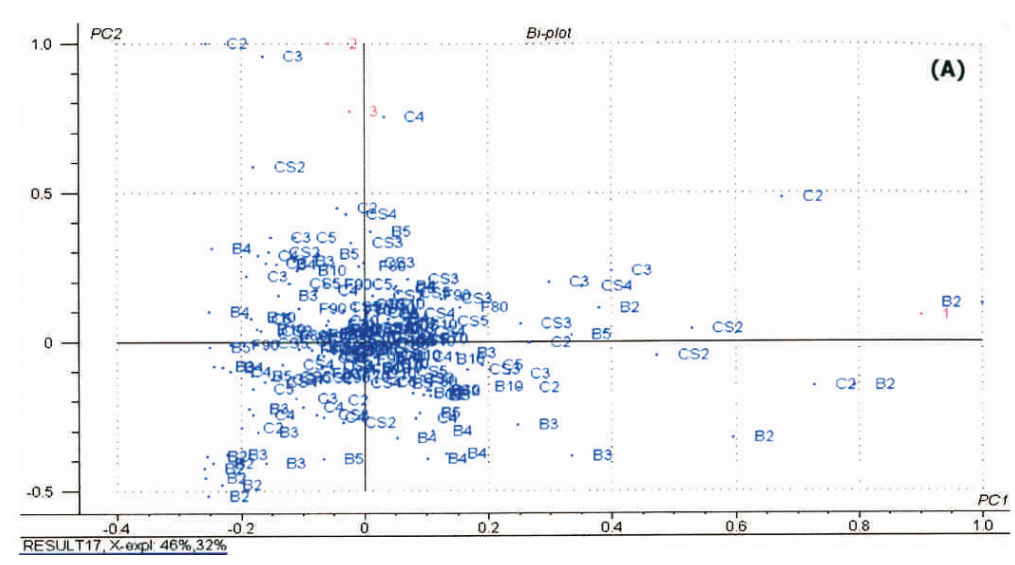

FIGURE 1 - PCA of the four techniques and the five impregnation concentrations tested - globule No.3.

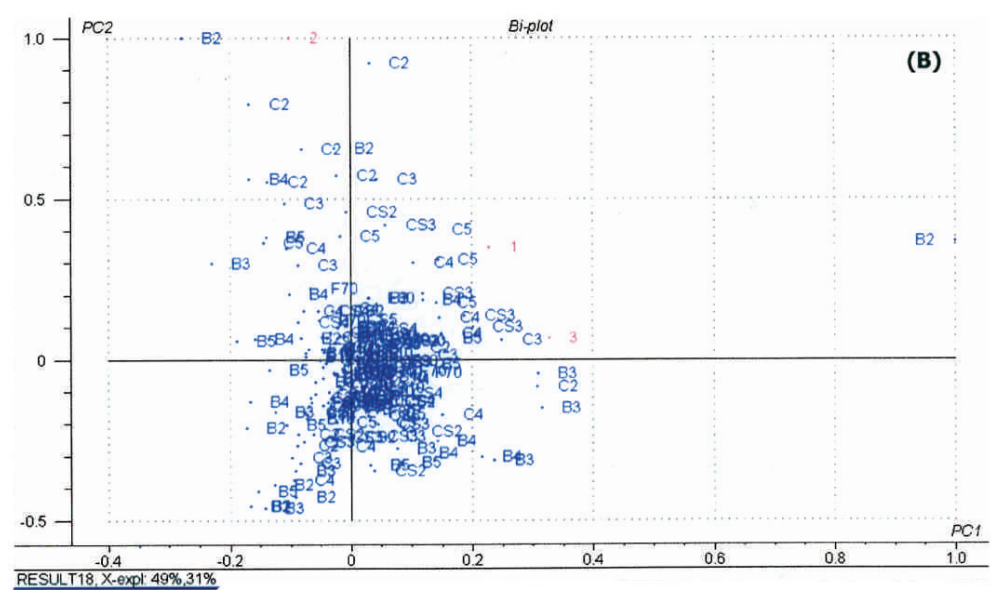

FIGURE 2 - PCA of the four techniques and the five impregnation concentrations tested - globule No 5.

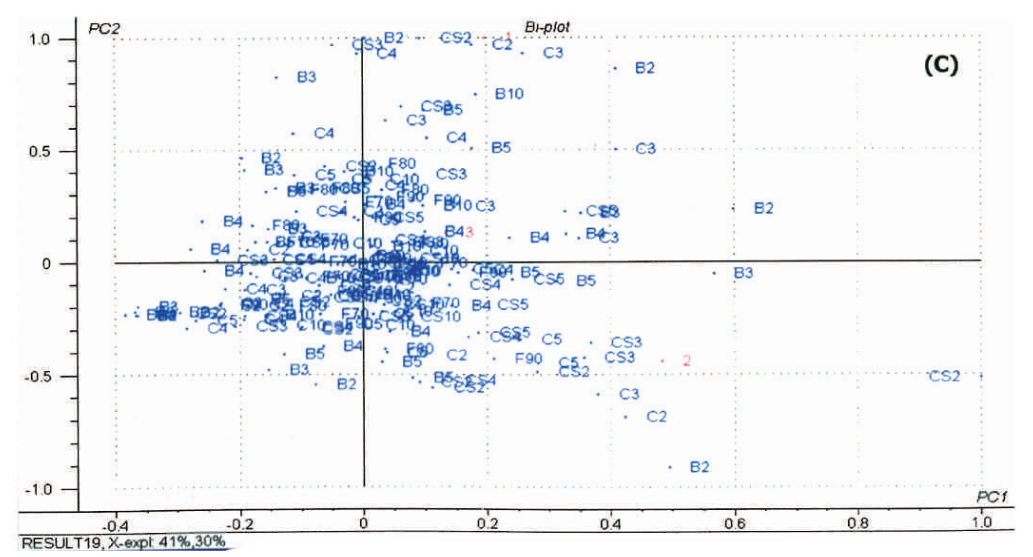

FIGURE 3 - PCA of the four techniques and the five impregnation concentrations tested - globule No 7.

other ones (Figures 1 and 3), it can be seen that there is a difference between the sizes of the globules. The results for the globule $\mathrm{N}^{0} .5$ are closer to each other and are less dispersed, i.e. they are closer to the origin $(0,0)$.

Regarding the drying time (Table VIII) it is observed that with the increasing of the concentration of impregnation and the size of the globule there is an increase of the drying time. However, drying at room temperature is not possible in the routine of a pharmacy with homoeopathic compounding. The dispensation of the undried medicine may cause the 
TABLE VIII - Drying time of the samples at room temperature from 2 to $5 \%(\mathrm{v} / \mathrm{w})$ and with a stove at $45 \pm 3^{\circ} \mathrm{C}$ at $10 \%(\mathrm{v} / \mathrm{w})^{*}$

\begin{tabular}{|c|c|c|c|c|c|c|}
\hline & \multirow{2}{*}{ Technique } & \multicolumn{5}{|c|}{ Time (minutes) } \\
\hline & & $2 \%(v / w)$ & $3 \%(v / w)$ & $4 \%(v / w)$ & $5 \%(v / w)$ & $10 \%(v / w)$ \\
\hline \multirow{6}{*}{ 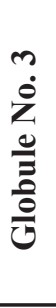 } & A-glass & 55 & 65 & 98 & 105 & $120^{*}$ \\
\hline & B-paper & 90 & 115 & 165 & 180 & $105^{*}$ \\
\hline & C-cup & 75 & 95 & 120 & 120 & $105^{*}$ \\
\hline & D-BHP $(70 \% \mathrm{v} / \mathrm{v})$ & - & - & - & - & $105^{*}$ \\
\hline & D-BHP $(80 \% \mathrm{v} / \mathrm{v})$ & - & - & - & - & $90^{*}$ \\
\hline & D-BHP $(90 \% \mathrm{v} / \mathrm{v})$ & - & - & - & - & $90 *$ \\
\hline \multirow{6}{*}{ 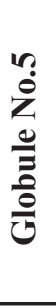 } & A-glass & 98 & 135 & 95 & 172 & $45^{*}$ \\
\hline & B-paper & 110 & 130 & 142 & 135 & $55^{*}$ \\
\hline & C-cup & 102 & 115 & 165 & 165 & $45^{*}$ \\
\hline & D-BHP(70\% v/v) & - & - & - & - & $78^{*}$ \\
\hline & D-BHP( $80 \%$ v/v) & - & - & - & - & $90^{*}$ \\
\hline & D-BHP( $90 \% \mathrm{v} / \mathrm{v})$ & - & - & - & - & $90^{*}$ \\
\hline \multirow{6}{*}{ 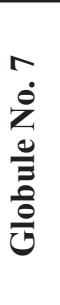 } & A-glass & 105 & 120 & 135 & 185 & $80^{*}$ \\
\hline & B-paper & 122 & 135 & 165 & 172 & $110^{*}$ \\
\hline & C-cup & 112 & 168 & 195 & 198 & $110^{*}$ \\
\hline & D-BHP(70\% v/v) & - & - & - & - & $110^{*}$ \\
\hline & D-BHP( $80 \% \mathrm{v} / \mathrm{v})$ & - & - & - & - & $100^{*}$ \\
\hline & D-BHP( $90 \% \mathrm{v} / \mathrm{v})$ & - & - & - & - & $100^{*}$ \\
\hline
\end{tabular}

growth of microorganisms inside the bottle, since the globules are consisted of sucrose. It is recommended to use a stove at $45 \pm 3{ }^{\circ} \mathrm{C}$ to accelerate the drying process, thus spending less time.

The agglutination and deformation were observed in the globules No.3 in simple and triple impregnation and at No 5 in simple, when the concentration at $10 \%(\mathrm{v} / \mathrm{w})$ D-BHP was used.

\section{CONCLUSIONS}

The result of the content uniformity performed by impregnating homeopathic globules with hydroalcoholic solution of minoxidil $2 \%(\mathrm{p} / \mathrm{v})$, and the statistical analysis data enabled the evaluation of the four variables mentioned in this paper (size of the globules, concentrations of the solutions to impregnate, alcoholic content of the impregnating solution and the techniques), in this way the following conclusions were taken:

The best results were obtained with the concentrations at $5 \%(\mathrm{v} / \mathrm{w})$ and $10 \%(\mathrm{v} / \mathrm{w})$, using the A-glass technique. However, the second concentration requires a stove at $45 \pm 3{ }^{\circ} \mathrm{C}$ for drying the globules, when they have not been deformed. The larger was the volume used in the globule impregnation the longer is the drying time at room temperature. In this way, it is necessary to use a stove for to complete the drying of the globules.

Concerning the concentration of hydroalcoholic solution of minoxidil, for the globules $\mathrm{N}^{\circ} .3$ and 7 , the solution at $70 \%(\mathrm{v} / \mathrm{v})$ showed the best results and for the globule $\mathrm{N}^{\mathrm{o}} .5$ it was the solution at $90 \%(\mathrm{v} / \mathrm{v})$.

According to the PCA graphics, the globule $\mathrm{N}^{\circ} .5$ produced more uniform impregnation when the four techniques and the five impregnation concentrations were compared. The best technique at a concentration of $5 \%$ $(\mathrm{v} / \mathrm{w})$ is the A-glass.

There is no statistically significant differences for the concentrations from 2 to $5 \%(\mathrm{v} / \mathrm{w})$ in the globules No.5 and 7, according to ANOVA, however there is statistically significant difference for the globule $\mathrm{N}^{\circ} .3$ in the technique $\mathrm{B}$-paper $\left(\mathrm{F}_{\text {calculated }}>\mathrm{F}_{\text {critical }}\right)$.

For the $10 \%(\mathrm{v} / \mathrm{w})$ concentration in the globule No.5, the three techniques (A-glass, C-glass, D-BHP) are statistically different according to PCA graphics.

For the A-glass, B-paper and C-cup techniques, the higher the concentration of impregnations the lower the results of variance will be.

This paper recommends that the impregnation of 
the globules use the A-glass technique with the globule $\mathrm{N}^{\circ} .5$ at a impregnation concentration of $5 \%(\mathrm{v} / \mathrm{w})$, keeping the bottle closed for 2 minutes and with the drying at controlled temperature, thus being in accordance to what is recommended in the latest edition of the Brazilian Homeopathic Pharmacopeia $3^{\text {rd }}$ edition- the volume of impregnation has to be at least of $5 \%(\mathrm{v} / \mathrm{w})$ and the drying of the impregnated globules has to be done in a stove at $45 \pm 3{ }^{\circ} \mathrm{C}$ (Farmacopeia Homeopática Brasileira, 2011).

\section{REFERENCES}

\section{ASSOCIAÇÃO BRASILEIRA DE FARMACÊUTICOS} HOMEOPATAS. Manual de normas técnicas para farmácia homeopática: ampliação dos aspectos técnicos e práticos das preparações homeopáticas. 4.ed. Curitiba: ABFH, 2007. $182 \mathrm{p}$.

ARAÚJO, T.L.; MAZZI, J.L.; CHAUD, M.V.; GUTIERREZ, M.A.; FONTES, O.L. Validação de técnicas e métodos de impregnação de glóbulos homeopáticos. Cult. Homeopát., v.3, n.9, p.8-16, 2004.

CALLEGARI-JACQUES, S.M. Bioestatística: princípios e aplicações. Porto Alegre: Artmed, 2003. 255 p.

DIEHL, E.E.; SONAGLIO, D.; LIMA, N.F.L.; BACKES, S. Estudo dos fatores impregnação e secagem nas características de glóbulos utilizados em homeopatia. Braz. J. Pharm. Sci., v.44, n.1, p.143-150, 2008.

FARMACOPEIA Brasileira. 5.ed. Brasília: ANVISA, 2010. v.1-2.

FARMACOPEIA Brasileira. 4.ed. São Paulo: Atheneu, 1996. Parte 1, Fascículo 1.

FARMACOPEIA homeopática brasileira. 3.ed. São Paulo: Atheneu, 1997.

FARMACOPEIA homeopática brasileira. 3.ed. Brasília: ANVISA, 2011.p.40

FARMACOPOEA homeopatica de los estados unidos mexicanos. 1.ed. México: Comisión Permanente de la Farmacopea de los Estados Unidos Mexicanos, 1998. p.???

Food and Drug Administration. Guideline on general principles of process. Available at: www.fda.gov/cder/guidance/pv/ htm. Accessed on: 15 Dec. 2005.
FONTES, O.L. Farmácia homeopática: teoria e prática. 4.ed. Barueri: Manole, 2013.389 p.

GERMAN homeopathic pharmacopoeia. 1.ed. London: British Homeopathic Association, 1978. Suppl.5, 1991.

GUTIERREZ, M.A.; MACIEL, R.L. O comportamento da farmácia homeopática em relação às técnicas apresentadas pelo manual de normas técnicas e a FHB: uma visão do estado de São Paulo. 2.ed. In: Congresso Pan-Americano de Medicina Homeopática, 58., Ribeirão Preto, 2001. Resumos. São Paulo: ABFH, 2001.

GUTIERREZ, M.A. Validação da técnica de impregnação de glóbulos homeopáticos. Rev. Homeopát. v.66, n.2, p.27-35, 2001.

HOMEOPATHIC pharmacopoeia of India. 2.ed. New Delhi: Govt. of Indian, Ministry of Health \& Family Welfare, 1984. v.2, 208 p.

KAYNE, S.B. Homeopathic pharmacy an introduction and handbook. New York: Churchill Livingstone, 1997. 236 p.

LEITE, F. Validação em análise química. 5.ed. Campinas, SP: Editora Átomo, 2008. p. 119-124.

MASSART, D.L.; VANDEGINSTE, B.G.M.; BUYDENS, L.M.C.; JONG, S.; LEWI, P.J.; SMEYERS-VERBEKE, J. Data handling in science and technology: handbook of chemometrics and qualimetrics. Amsterdam: Elsevier, 1998. v.20A.

MENDHAM, J.; DENNEY, R.C.; BARNES, J.D.; THOMAS, M.J.K. Vogel: análise química quantitativa. 6.ed. Rio de Janeiro: LTC, 2008. p. 63-77

PINHEIRO, M.S.; GARCIA, S. Perfil das farmácias com manipulação homeopática dos estados do Espírito Santo e Rio de Janeiro: questionário de avaliação das técnicas de impregnação de glóbulos. Cult. Homeopát., v.17, p.18-20, 2006.

POZETTI, G.L.; SILVA, R.F.P.; PIZZOLITTO, E.L. Técnicas de impregnação de glóbulos homeopáticos: análise laboratorial. Rev. Racine, v.66, p.50-56, 2002.

ROCHA, L.; AFONSO, C.; LUNA, I.S.; SÁ, I.M. Otimização da metodologia para impregnação de glóbulos aplicada a farmácias homeopáticas. Homeopát. Bras., v.6, n.2, p.77$81,2000$. 
SANDOVAL, L.G. Farmacopea homeopatica mexicana. 2.ed. México: Farmacopeia Mexicana, 1961. 367 p.

SYNDICAT des pharmacies et laboratories homeopathiques - homeophathie - pharmacotechinie et monographies des medicaments courants. Lyon, 1979. v.2.

TÉTAU, M. Hahnemann, muito além da genialidade: vida e obra. São Paulo: Editora Organon, 2001. 264 p.

THE HOMEOPATHIC Pharmacopoeia of the United States. 9.ed. Falls Church: American Institute of Homeopathy, 1999.
THE MERCK index: an encyclopedia of chemicals, drugs, and biologicals. 14.ed. New Jersey: Merck, 2006. 1v.

USP - The United States Pharmacopoeia. 27.ed. Rockville: United States Pharmacopeial Convention, 2004. p. 1250

VARELLA, C.A.A. Análise de componentes principais. Programa de Pós-graduação em Agronomia - CPGA-CS, Universidade Federal Rural do Rio de Janeiro (UFRRJ), Seropédica, 2008. Available at: http://www.ufrrj.br. Accessed on: 15 Aug. 2012.

Received for publication on $19^{\text {th }}$ May 2013 Accepted for publication on $01^{\text {st }}$ August 2013 